\title{
EU-Centric Governance in Sport? The Slovenian Experience with the White Paper Process
}

\author{
Simona Kustec Lipicer
}

\begin{abstract}
A synthesis of existing academic, expert and everyday practical political literature demonstrates that we can trace many different approaches to the phenomena of governance. Based on the political sciences, particularly policy literature, the governance concept is most frequently connected with an analysis of the relations between actors or institutions of the state and society at different political levels. Use of the governance concept is also becoming increasingly popular when discussing sports issues, especially when the multi-level or global sport perspective is in question. This article aims to confront the national perspectives and understandings of, as well as attempts at, sports governance, in relation to multi-level ones. This refers specifically the EU, because over the last few years, not only have states expanded their traditional concerns with health and social security to encompass leisure and cultural life, including sport, but the EU has also implemented different activities concerning sport issues. This particularly emphasises the extent and importance of the relations that key national policy actors have established with themselves and especially towards supra-national (EU) actors in the processes of creating common EU sports policy directions as part of preparing the White Paper on Sport (2007). It does this by analysing the available official documents, records and statistics relating to the issue, as well as interviews conducted in spring 2007 with representatives of the state and sports-governing bodies in Slovenia. The conclusions of the analysis indicate a predominantly EU-centric type of multi-level governance approach and make some observations about the EU's future development and how this could impact the development of (sub)national sports policy.
\end{abstract}

A SYNTHESIS OF EXISTING ACADEMIC, EXPERT AND EVERYDAY PRACTICAL POLITICAL literature demonstrates how we can trace many different approaches towards the phenomena of governance, to various fields of social activity. Based on the political sciences, particularly policy literature, the governance concept is most frequently associated with an analysis of the relations between actors or institutions of the state and society at different political levels.

The governance concept is also increasingly used when discussing sports issues, particularly when the multi-level or global sport perspective is in question. Therefore, this article aims to examine the national and sub-national perspectives and understandings of, as well as the attempts at, sports governance, in relation to the supra-national ones. This is done with specific reference to the European Union (EU), and considers that in the last few years the EU has been increasingly involved in different activities concerning sport issues. As Sam and Jackson (2004) emphasise, sport policies are underpinned by particular interpretive

An earlier version of this article was presented and discussed at the $2^{\text {nd }}$ Annual Sport\&EU Workshop in Chester (UK) 6-7 July 2007. I would like to thank Professor Richard Parrish (Edge-Hill University), Dr. Andy Smith (University of Chester), Alexandre Mestre (PLMJ Law Firm, Portugal) and Borja García (University of Loughborough) for their comments and ideas during previous work on the article. The author would like to thank two anonymous reviewers for their valuable and very in-depth comments and proposals on previous drafts. Special thanks also to Murray Bales for his invaluable editing assistance. Responsibility for what has been written is, of course, solely the author's.

ISSN 1815-347X online - Kustec Lipicer, S. (2007). 'EU-Centric Governance in Sport? The Slovenian Experience with the White Paper Process', Journal of Contemporary European Research, Vol. 3, No. 3, pp. 273289. 
frameworks or paradigms. These paradigms shape: (a) the construction of policy problems; (b) the alternative approaches to resolving these problems; and (c) what is considered to be an acceptable government intervention. This article seeks to investigate the presence of all three sets of paradigms between the policy actors involved at different political levels. The analysis focuses on recognising the elements of multi-level governance processes that were expressed when preparing the European Commission's White Paper on Sport. The analysis concentrates on the formulation phase of the White Paper, with special attention paid to the (sub)national (Slovenian) type of involvement. When defining the governance idea, a deliberate decision was made not to distinguish in advance between its different aspects because the frequently intertwining nature of governance characteristics enables us to detect a probable specific type of governance approach in the analysed case. The analysis thus involves an understanding of the roles played by policy actors involved in preparation processes at various political levels, along with activities and jurisdictions undertaken to cooperate in these processes.

Multiple methods are used to collect the relevant data to verify the emphasised relations and processes. They include a legal analysis of the roles and jurisdictions of various policy actors in Slovenian sport legislation and in existing EU legal documents dealing with sports policy issues. Official documents, records and statistics relating to the research issue, including reports from meetings organised to discuss the White Paper process are also analysed. Another important source of information was interviews conducted with top Slovenian sports officials who were officially involved in the preparations for the White Paper. ${ }^{1}$

\section{The Idea of Governance}

The idea of governance, although not new, is currently one of the most popular political concepts or ideas in the contemporary academic environment. Scholars from economics, political science, sociology, international relations, as well as public policy and administration have been paying a lot of attention to the new forms of governance and the reallocation of authority (Hooghe and Marks 2001). ${ }^{2}$ The roots of the idea can be traced back to the late 1960 s when it initially started to develop in the fields of organisation sociology and management sciences and was then extended to almost all branches of the social sciences in the 1980s (Schneider 2004: 25). ${ }^{3}$ In the field of political science, governance terminology expanded in the mid-1990s by referring generally to ways of understanding the breadth of political phenomena through relationships between the state and civil society when pursuing collective interests (Pierre and Peters 2005: 6). This emphasis on the state-society relations reflects some sort of common understanding of governance that has been significantly upgraded over time. Today, the synthesis of the governance literature in the field of political science shows that the initial understanding of governance as an idea has been slowly yet constantly transforming from a vague to a solid political science concept and theory (see Mayntz 2004; Héritier 2002; Kohler-Koch 2005).

\footnotetext{
${ }^{1}$ The interviews were conducted in May and June 2007. Three interviews were conducted at the Directorate for Sport with the Director and the Secretary Generals responsible for EU and Internal Affairs, respectively, two interviews with the Secretary General and the Director of the Top Sports Committee at the Slovenian Olympic Committee - the Association of Sport Federations and one interview with the representative of the EC in Slovenia. The interviewees were chosen according to the criteria of the responsibilities and jurisdictions they undertake in the analysed processes and were all asked the same questions relating to the following: a) the perceptions of the formal legal position and jurisdictions in the processes of preparing the White Paper on Sport; b) their impressions and assessments of their positions and jurisdictions in actual everyday processes; and c) their perceptions of the relations established between the policy actors involved at different political levels.

${ }^{2}$ At first sight, it might be dubious or even surprising that the authors differentiate between the political sciences and public policy and administrative approaches to governance. The reasonableness of this decision is explained later in this article.

${ }^{3}$ Currently it seems that the governance concept is more actively present in the field of organisational management, commonly known as corporate governance. For more on this see Aguliera and Cuervo-Cazurra (2004).
} 
Hence, several understandings of governance in political science literature can be detected. On one side, it can be used as a term to describe the prevailing manner of organising political life, while on the other side ('only') as an alternative approach to analysing actors' mutual relations in decision-making processes. Wälti et al. (2004: 83) understand it as a concept that can be used to describe various activities within the political sphere, from labelling changes in the management of public policies to the transformation of coordination between the state and society; this is very close to the idea of policy networks (Börzel 1997). Given this possible contextual width, Treib, Bähr and Falkner (2007) also stress the institutional aspect of the governance concept, reflecting the hierarchy, centrality and (non-) institutionalisation of interactions. The same authors also point out the policy dimension of governance, which relates to the processes of implementation and policy outputs along with the roles of different types of policy actors in those processes; and to the political dimension of governance which refers to (a) the processes of political management that encompass the normative bases of political rule, $(b)$ the prevailing style of managing public affairs, and (c) public resources. In this sense, it seems that the idea of governance is once again trying to open up the vital issues of the responsibilities, legitimacy and transparency of public authorities in political discourse (Robinson 2004). ${ }^{4}$

In its most broad sense we can therefore understand governance as a new or modern form of state theory which is, according to Schneider (2004), close to the structural and institutional state theories of social co-ordination. ${ }^{5}$ Although when speaking about these macro patterns Schmidt (2006) claims that in the case of national policy-making processes, actors' complex relationships still fall within a continuum from the classical political theories of statism or corporatism; while with supra-national arrangements, such as the EU, they come close to a semi-pluralist, but still not an ideal governance system. ${ }^{6}$

The discussed theoretical understandings of governance may clearly convince us that the one and only truth of its understanding cannot be dispelled. Being aware that most theoretical standpoints are based on empirical findings of analysing different systems and/or policy fields, the central question therefore remains whether we can understand governance as an all-binding political-policy-polity idea, or as an independent individual approach of each one. One alternative that can help us solve this academic problem might be found in the spectrum of everyday practical political understandings and definitions of governance. Analysing some of the basic standpoints of the so-called 'codes of governance' (Aguliera and Cuervo-Cazurra 2004) shows that the patterns of academic findings are also very similar when set on more practical grounds. As can be seen in the following synthesis of some of everyday political definitions of governance, their content and, thereby, understandings, are at least as broad and vague, inexact and/or boundless, as the academic ones can be. ${ }^{7}$ The whole extension and popularity of the governance terminology on 'practical political' grounds may be found in the idea of so-called 'good governance' stated in various political documents that define it in different manners. The EU for example understands the concept of governance as a power of its citizens in relation to the authorities (European Commission 2001), the United Nations sees it as a process of decision-making and (non) implementation (United Nations 2007), while the World Bank interprets governance as the traditions and

\footnotetext{
${ }^{4}$ Therefore we can conclude that the concept of governance is wider than the idea of government, which more or less deals (only) with the maintenance of social order within one territory that is being implemented by the executive branch of authority (Aguliera and Cuervo-Cazurra 2004).

${ }^{5}$ Rhodes (1996) similarly connected the understanding of the concept of governance with at least six different meanings: the minimal state, corporate governance, new public management, good governance, social-cybernetic systems and self-organised networks.

${ }^{6}$ The key reason lies in differences in the policy-making process since in the phase of policy formulation private interests have reasonably open access and influence while, in implementation, when regulatory and legalistic enforcement is the rule, they do not (Rhodes 1996: 670-71).

${ }^{7}$ According to Aguliera and Cuervo-Cazurra's findings (2004: 436), countries with more effective governance systems in terms of the overall legal system, that is, a common-law legal system, are more prone to continue improving their systems and to develop codes, although their picture might be understand as only onesided, while the research has been oriented to a national country's perspectives and it leaves out the crucial aspect of governance that lies in its global emphasis.
} 
institutions via which authority in a country is exercised for the common good ${ }^{8}$ (World Bank 2007). Finally governance can also relate to practical guidance for the private sector when co-operating with the state (Governance Hub 2007).

The described understandings of both academic and everyday practical, political, notions of governance point to a variety in its meanings from the very narrow, focusing on special political arrangements, to the very broad, encompassing the whole spectrum of politics. This article reveals the level and nature of governance elements in the case of preparing the White Paper on Sport. It does this through an analysis of the ongoing processes, activities and relations established between the policy actors involved at the sub-national, national and supra-national levels. This means that the idea of governance is intentionally and not exhaustively defined in advance, although it could be argued that in its essence it is closer to the policy perspective.

\section{Multi-level Governance}

When discussing global political phenomena, the idea of governance is even more popular and fashionable than when it relates solely to the national level. It is frequently expected that this type of new practice should help solve the efficiency and/or legitimation crisis of global or supra-national structures (Aguliera and Cuervo-Cazurra 2004). When it comes to the EU system, the idea of governance has also been seen as crucial when searching for the best possible decision-making system. In the 1970s, when European integration seemed to have come to a halt, the question of who was running the integration process altogether became less interesting, while the revival of the supranational versus intergovernmental debate in the late 1980s no longer helped to fully understand the nature of politics and policy in the EU. This stimulated the need to develop new ideas to explain how the EU works (Cram 2001: $151,152)$. In the early 1990 s the concept of governance, and specifically multi-level governance, was proposed, mainly by German and Dutch public policy scholars, as an influential theoretical perspective. They saw the EU as a multi-level system of governance where private and public actors at the supranational, national and sub-national levels interact within highly complex networks to produce policy outcomes (Börzel 1997). The initial idea of multi-level governance in the EU thus pointed to a system of continuous negotiations among nested governments at different territorial levels (Marks 1993: 392) in ever more complex policy processes (Richardson 1996; Andersen and Eliassen 2001) consisting of the stages of agenda-setting and formulation, decision-making and, finally, the implementation and enforcement of a policy problem or issue (Cram 2001: 155).

In its broadest sense, the EU functions as a special type of political system because it produces legislation and policies (Hix 1999), and creates a system of governance that can be seen in a range of different policy outcomes produced by policy actors aiming to ensure values and objectives in the cases of market and social integration (Cram 2001: 161). The idea of a complex and frequently messy system of various policy actors that in their mutual relations form a type of a special network of governance has frequently been compared with the idea of 'new medievalism', thanks to its having some similarities with the polycentric forms of government developed at the city level in the United States (Grant 2003). As emphasised by Wright (1996: 148), the crucial predisposition of successful network relationships lies in effective co-ordination between actors from various political levels involved in a specific stage of policy processes. The public policy literature distinguishes various types of co-ordination at (sub-)national and supranational levels from the anticipatory, active, reactive, formal and informal, vertical and horizontal, negative and positive, policy and procedural processes. These distinctions are quite blurred in practice and generally fail to provide a framework which links the various forms (Wright 1996: 148).

\footnotetext{
8 This includes: (i) the process by which those in authority are selected, monitored and replaced; (ii) the government's capacity to effectively manage its resources and implement sound policies; and (iii) the respect of citizens and the state for the institutions that govern the economic and social interactions among them (Aguliera and Cuervo-Cazurra 2004).
} 
Despite these warnings, the nature and intensity of actors' co-ordination can be very productive for understanding their mutual relations and, therefore, the type of multi-level governance. Based on Selznick's functions of institutional leadership, Wright (1996: 148-149) proposed the following functions of co-ordination that also provide the common thread of the governance arguments used in this study of the White Paper:

1) the definition of the actors' mission and role (the 'creative task of setting goals');

2) the institutional embodiment of purpose (the capacity 'to build policy into an organization's social structure');

3) the defence of institutional integrity ('maintaining values and institutional identity');

4) the ordering of internal conflict ('reconciling the struggle between competing interests').

Hooghe and Marks (2001) go further and propose that it is also sensible to differentiate two types of governance according to the nature of the jurisdiction. The first mode is more oriented towards broader political contents dealing with the dispersion of authority but intended to be permanent and with a limited jurisdiction and number of levels, while, contrary to the former, the second mode is task-specific, overlapping between different levels and as such the number of jurisdictions is unlimited and intended to be flexible (Hooghe and Marks 2001). This last mode, as emphasised by Grant (2003), is closer to the ideal understanding of the multi-level, policy-based, governance approach, for which it is significant that in contrast with more traditional forms of decentralisation the number of jurisdictions is not limited, that the jurisdictions operate on diverse territorial scales rather than a few levels (even across national borders) and are task-specific rather than multi-task (Grant 2003).

In 2001 the European Commission introduced the White Paper on European Governance, which strongly considered the theoretical ideas of multi-level governance by proposing a set of recommendations for how to enhance democracy in Europe and increase the legitimacy of institutions through openness, participation, accountability, effectiveness and coherence (European Commission 2001: 10). This White Paper not only gave a great impetus to translating academic ideas into everyday policy-making, but also encouraged the significance of establishing co-operative relationships between the various types of policy actors involved in policy processes.

While many concrete examples of various analyses confirm the usefulness of the theoretical framework in the case of multi-level governance in the EU, several critics can also be found which claim that, rather than a coherent theory, multi-level governance is only an eclectic collection of points concerned with a static analysis of the nature of the EU (George and Bache 2001: 25). Given these limits, which were exceeded by understanding the EU as a system of supranational governance, it is possible to see the idea of multi-level governance as a useful tool in the following analysis. Based on the emphasised contents, governance arguments or criteria of actors' roles, policy capacities, integrity, conflict reconciliation and jurisdictions would be more precisely considered when assessing the mutual relations between the policy actors involved at various political levels, who were co-operating between themselves within the processes of formulating the contents of the White Paper on Sport, thus creating the embryos of sports policy at the EU level.

\section{Sport Governance in Multi-level Circumstances}

The idea of governance in the political sciences is close to all possible social arrangements and activities established by the state or state-like authorities, including those of sports society. Different types of state-initiated activities extend far back into history and involve various forms (see Houlihan and White 2002, Henry 2004). Most frequently the spectrum of public interest in sport is connected with the belief that participation in sport facilitates social integration and equality, supporting economic development or even helping to build a sense of national identity. From the perspective of the governance idea, the crucial modern 
pointers of state-society relations can be seen in the establishment of explicit sport legislation and state-based institutions, the roles and jurisdictions of state and sports society actors as well as the various types of mechanisms used to define and fulfil a public interest in sport. One of the best known comparative examples of combining theoretical governance considerations with empirical findings on national sport governance systems was prepared by Chaker (2004). ${ }^{9}$ In this study, the author used the level of regularity and accountability based on statutory provisions as crucial elements of good governance. When classifying the states according to these elements, he concluded that most systems have established and promoted, at least, some sort of indirect state interest in sport, relative to sports organisations.

Currently the position of sport and consequently its role in (public) policies has gained in importance. It has developed mass audiences and effectively become a global phenomenon. ${ }^{10}$ Although it seems the traditional nation-state based governance idea is being replaced by global political imperatives, the emphasises frequently remain very similar, given that global political initiatives also need to seek legitimacy for their making (Banchoff and Smith 1999, Houlihan 2003, Crombez 2003, Allison 2006, Gloub 2007). Considering this, there have been many international or even global attempts at regulating sport through common governmental and sports organisation initiatives such as those of the Council of Europe, the World Anti-Doping Agency or the European Union. The common point of these supra-national interventions lies in the idea of so-called 'sport governance'. As defined by the Council of Europe's Recommendation Rec (2005), the principle of good governance in sport equally concerns the public administration sector of sport as well as the non-governmental sports sector. The idea of good governance refers to a complex network of policy measures and private regulations used to promote integrity in management of the core values of sport such as democratic, ethical, efficient and accountable sports activities (Council of Europe 2005). Although this document was the first directly oriented to the issue of sport governance, a majority of the others that were recently established, regardless of the political level, also involves similar elements. The latest in this regard is the EU's White Paper on Sport (2007), published on 11 July 2007.

\section{Building the EU's Sports Policy}

The history of the EU's interest and activities regarding sport is relatively new, although some indirect attempts, mainly in the work of the European Court of Justice (ECJ), have been seen since the mid-1970s (Parrish 2003: 85-107). The first direct political, and hence, legal attempt involving sports policy results from the 1995 Bosman ruling, emphasising calls by EU institutions and some nation-states to grant sport a legal basis within the European Treaty (Parrish 2003: 15). In 1997 a European Parliament Resolution was also adopted on the role of the European Union in the field of sports. ${ }^{11}$ This document calls on the European Commission to take account of sport across the entire spectrum of its activities, particularly in regional, social, educational, youth training and health fields (European Parliament 1997a: 252). Following this, the Heads of States and Governments of the EU met in Amsterdam and decided to attach a non-binding Declaration on Sport to the Amsterdam treaty calling on European Union bodies to listen to sports associations when important questions affecting sport are at issue, especially the characteristics of amateur sport. ${ }^{12}$ Since then, the Commission's Education and Culture Directorate has undertaken a lot of sports-related work.

\footnotetext{
${ }^{9}$ Although the title of the study refers to the idea of governance, the criteria employed in comparison are not so directly oriented to the aspects of governance as in classical elements of governmental (in)activities or levels of intervention in sport.

${ }^{10}$ I am aware that we can discuss this statement in relation to the American model of sport, known for its almost complete state absence, as well as for not giving international competition the key focus.

${ }^{11}$ Having referred to its previous resolutions on the relationship between the European Community and sport and in particular its resolution of 6 May 1994 on the European Community and sport (1994).

${ }^{12}$ European Council (1997) Declaration No.29, on sport (Amsterdam Declaration on Sport) was attached to the Treaty of Amsterdam amending the Treaty on European Union, the Treaties establishing the European Communities and certain related acts.
} 
First, the Sports Unit within the Commission's DG emerged, undertaking a key institutional role by initiating a process of dialogue and consultation with the other sports-interested institutions and individuals. As a result of its previous work, in 1998 the Commission issued the paper on 'The Developments and Prospects for Community Activity in the Field of Sport', followed by the Consultation document 'The European Model of Sport' (1998) where sport is identified through its educational, public health, social, cultural and recreational functions. In addition, the organisation of sport in Europe, its features and recent developments were determined (European Commission 1998). A series of European Commission activities involving a broad range of consultations was undertaken and finalised in the Helsinki Report on Sport presented by the European Commission (1999) to the European Council. In 2000, the Nice Declaration on Sport (European Council 2000) was adopted as the European Council's response to the Commission's Helsinki report. It called upon Community institutions to take due account of the educational values of sport in its actions and demanded that the social and cultural dimensions of sport should feature more prominently in national and Community policies. The institutional complexity of the EU's involvement in sport reached its peak in 2004 which is, from the Slovenian perspective, especially important because it coincided with the country's official accession to the EU. It was actually from this point that it is possible to formally begin to search for potential multi-level governance relations. At the highest political level these supranational governance elements can first be seen in the contents of the Treaty Establishing a Constitution for Europe (2004) where sport was paid special consideration in Article III-282 $\mathrm{g}$ of Section 5 stating that Union action shall aim at developing the European dimension in sport by promoting fairness and openness in sporting competitions and co-operation between bodies responsible for sports, and by protecting the physical and moral integrity of sportsmen and sportswomen, especially young sportsmen and sportswomen. The treaty also predicted co-operation with so-called third countries and competent international organisations in the field of education and sport (in particular with the Council of Europe) but it has never come into force due to the negative referenda in France and the Netherlands that stopped the ratification process. From the EU sports perspective, it is clear to see that although the whole debate on the constitutionalisation of sport in the EU with the interventions of the European Council and the Commission had an effect on framing the issue 'sport', thus redefining sports policy (García 2007: 37), it has so far failed to be formalised due to the non-ratification of the Constitutional Treaty. Slovenia, as one of the EU member states that ratified the Treaty, therefore indirectly supported the legitimacy of the EU statement on sport with its signature, although no public consultations or discussions on the contents occurred in the period when debates about the Treaty's contents were topical. ${ }^{13}$

The continuing processes of creating the EU's sport policy have, despite the current deadlocks in amending the EU Constitution, been very alive. In the summer of 2007 two more crucial events happened. The EU launched an Intergovernmental Conference (IGC) in Brussels to revise its institutions and power-sharing system thorough the submission of the draft 'Reform Treaty'. As scheduled, the final draft was formally adopted at the Summit in Lisbon in October 2007 and it makes explicit reference to the specific nature of sport once again. Article 124(a) of the new treaty stipulates that 'The Union shall contribute to the promotion of European sporting issues while taking account of its specific nature, its structures based on voluntary activity and its social and educational function' (The Council of the European Union 2007). ${ }^{14}$ Almost parallel to these 'constitutional' processes, the Commission released the White Paper on Sport on 11 July 2007. This document may be currently understood as the key EU sports policy document, highlighting the economic,

\footnotetext{
13 Although ratification of the constitutional treaty can in the Slovenian case be understood as a high political act which was more or less self-evident and based on the still 'fresh' results of the national referenda for EU accession in 2003 , where almost $90 \%$ of all participants voted for Slovenia to join the EU. Hence extensive debates on the constitutional contents were not expected. The more active responses of the national and sub-national levels involved in the future, also in individual policy cases, may be expected.

${ }^{14}$ This new wording retains the substance of the proposed text in the aborted project to establish a new constitution for Europe (Article III - 282) and it is also in line with the Nice Declaration (2000), which made reference to the 'specific characteristics' of sport. The agreed text is now being submitted for ratification in all member states and is expected to be completed in time for the June 2009 European elections.
} 
societal and organisational roles of European sport as three crucial areas or functions of its making. In this regard, sport is defined as an area of human activity that greatly interests the European Union's citizens and has enormous potential to bring them together by reaching out to all of them, regardless of their age or social origin (European Commission 2007a: 3). Meanwhile, it is also defined from the economic perspective as a dynamic and fast-growing sector with an underestimated macroeconomic impact that can contribute to the Lisbon objectives of growth and job creation. It is also seen as an alternative tool for local and regional development, urban regeneration or rural development, as well as having synergies with tourism, and stimulating the upgrading of infrastructure and the emergence of new partnerships for financing sport and leisure facilities (European Commission 2007a: 10). It should be noted here that the White Paper's contents will not be debated here since this is not the primary aim of this article; however, it is possible to assess the document from various possible 'governance viewpoints'. In one sense, it is the EU's first real attempt to create some kind of policy interpretations and directions in the broader field of sport in the EU as well as indirectly at (sub)national levels. This appears to see the EU assume the 'traditional' motives of nation-states' interests in sport. On the other hand, the document still remains a non-binding consultative paper, albeit one that sets out the potential means by which the EU could develop more binding policy alternatives in the future (Greenwood 2007: 183). In terms of governance terminology, we may regard the document, in its ideal form, as an example of a multi-task governance approach, pointing to task-specificity, the overlapping jurisdictions between different political and public-private levels, flexibility, and the openness and willingness for the full participation of all interested actors.

It can also be argued that the White Paper undertakes the function of a formal document that formulates policy directions in EU sport policy; but we could also understand it much more broadly. As already stressed by García (2007), the initial sports policy was just regulatory in nature and introduced through the so-called 'low politics route' which saw the EU institutions view the issue purely from the perspective of sport and its rules, however, after the Bosman case this narrow or low politics route evolved to encompass the sociocultural, educational and economic particularities of sport. In this sense, a clear shift in the EU's institutional interest in sport can also be detected, starting with the ECJ's judgements in cases of sport disputes, followed by the sporting-policy agenda-setting activities of the Commission and its Sports Unit, along with the Parliament's and Council's activities, and finally with the significant development which saw sport given a special position within the EU Constitutional Treaty. However, of all of these activities, it is without doubt, the White Paper on Sport, that is the most important development within EU structures, guaranteeing the potential development of a solid policy framework in the filed of sport at the EU level.

\section{Multi-level Governance in Sport in Practice: The Slovenian Background}

Despite the political activities of the EU in the field of sport, it is unlikely that some sort of binding EU sports policy will emerge in the near future, mainly because of the powerful influence of some international, private, sports organisations and federations. However, this does not mean that the White Paper, as the EU's foremost document on sport, should be overlooked. Rather, it may prove useful to examine the background to the creation of the White Paper, thus revealing the potential of possible future EU governance practices in sport, particularly in relation to the (sub)national governance practices. Therefore, the national governance perspectives are taking on an important role and need to be analysed.

When it comes to Slovenian sports policy, legally speaking, a democratically based sports policy first appeared in 1998 with the establishment of the 'Sports Act'. This was followed in 2000 by the second most important legal document called the 'National Programme of Sport in the Republic of Slovenia'. Despite the quite long period, from the country's independence in 1991 until 1998, of official absence of any kind of sports related legislation, sport itself has received a lot of attention from the state with the establishment of a ministry responsible for sport as well as a share of related public financing guaranteed since the beginning of the country's statehood in 1991. Furthermore, the state ratified various international conventions 
on sporting issues, despite the fact that no specific national formal legislation on sport then existed. ${ }^{15}$

With the adoption of both mentioned legal acts, the following fields of normative definitions, regulations and, in some sense, governance elements were also introduced:

a) public interest and consequently national and local programmes and strategies in sport, emphasising the sports education of pre-school children, pupils, youth, youth with special needs, students and the disabled, elite sport (both documents);

b) public tasks in sport, relating to the education and training of sport experts, academic and research activities, publishing, the establishment of an information system for sport, the enhancement of sport events and infrastructure, the fight against doping, and international activities;

c) the actors involved their jurisdictions and legally prescribed relations. A special position is given to the Expert Council of Sport as an expert counsellor of the ministry responsible for sport, sport public institutes, expert workers in sport, private work in sport, athletes and elite athletes, and inspection (Sports Act).

Sport from the nation-state perspective is defined as an important public good and an economic category that needs both state and sports organisations' incentives and support. Sport in this sense is used as a proper mechanism for helping an individual to find the equilibrium between his/her work and leisure, as well as to strengthen his/her health and creativity. It is also understood as an important ingredient of institutional upbringing and education, as well as a tool for shaping national identity (National Programme for Sport 2000). When analysing the contents of both national legal documents, we see that an important part of both is also dedicated to the recognition of the actors and/or institutions involved, with a special focus on their roles and possible mutual relations. Both acts predict in a normative manner a high level of co-operative relations at the local, national and international levels between representatives of the state and sports organisations on one side while, on the other, some types of relationships are even specifically defined. Article 5 of the Sports Act, for example, states that the National Programme of Sport can only be accepted by the National Assembly when the Olympic Committee of Slovenia - the Association of Sports Federations (OCS-ASF), as a key national representative of sports organisations, and the government reach a consensus on the programme. In case this does not happen, the programme can still be proposed to the legislative body but then the governmental Expert Council of Sport, composed of representatives of expertise, private sport workers or organisations, the OCS-ASF and national federations not included in the OCS have to agree with the contents.

These legally prescribed state-civil society relations also confirm that the relations between the state and sports society have always existed, with a growing emphasis given to the role of sport experts ${ }^{16}$ in policy-making processes. It emerges that the state applies different forms and mechanisms to foster co-operation with civil society. This may also be understood as an attempt to maintain quite a high level of social sport capital in the national policy. On the other hand, it still seems that the relations between the state and civil society are diffused since the state leaves decision-making processes to be led by civil society players ${ }^{17}$ and fosters the social sphere, yet it still legally and institutionally intervenes in the sports field.

\footnotetext{
15 The Act Ratifying the European Convention on Spectator Violence and Misbehaviour at Sports Events and in Particular at Football Matches (1990), the Act Ratifying the European Convention on Anti-doping (1992), the Act Ratifying the Nairobi Treaty on the Protection of the Olympic Symbol (1998). For more on these see Verovnik (1999).

${ }^{16}$ Although sports experts represent an important special group of policy actors defined in the Sports Act, it is unclear which characteristics and conditions need to be fulfilled to acquire the title of a sport expert. It could be guessed that this category is reserved for those who finish education courses at the Faculty of Sport which then give them a highly privileged and legally protected status compared to other professions where this kind of legal protection is not so self-evident nor accustomed.

${ }_{17}$ Comparative sports policy research results across Europe show that since the beginning of the 1970s governments have engaged more actively in sport and sport policy in many cases as a result of sport organisations' initiatives (Green and Houlihan 2006; Ibsen 2006).
} 
Further, the state is ever increasingly referring to international legislation and is thus giving over much of this area of policy responsibility to a supra-national level, constituted by new (state-type) supra-national policy players. The promotion of policy-making at the supranational level brings with it many reshaped issues, solutions, aims and mechanisms, as well as different positions, jurisdictions, new policy players and therefore also diverse relations. Likewise, nationally-based governance principles are predicted, international co-operation is also legally limited particularly in the National Programme of Sport. However, formally based supranational connections with regard to the EU, still cannot explicitly be found anywhere. Although this might be seen as surprising or odd when it comes to national activities in the field, at the same time it could be expected when we consider that the beginnings of the ongoing policy-making activities in the EU are still in their early stages (Kustec Lipicer 2007). ${ }^{18}$

\section{Figure 1: Governance in Slovenian sports policy}



\footnotetext{
${ }^{18}$ It is just a coincidence that the processes of establishing sports policy coincide time-wise with the current processes of amending the legislation at the national level and it should be expected that this fact would be used as an advantage to make better and more harmonised conclusions.
} 


\section{(In)Activity in the White Paper Processes: General vs. the Slovenian Perspective}

When processes connected with the preparation of the White Paper on Sport began, the reasons for closer co-operation between the EU, national and sub-national levels were also formally stated. Based on the White Paper on European Governance from 2001, the European Commission used a set of consultation tools, including the establishment of expert groups that reported on three key areas, different types of meetings, and internet consultations through the preparation of a broad and very complex questionnaire for everyone interested (European Commission 2007). As a consequence of the Commission's call to participate in the consultation processes, different representatives at the (sub)national levels were also called on to participate.

In Slovenia, it turned out that few consultation activities had been undertaken at the nationstate and sports society levels. According to the characteristics of the initial phases of the process of adapting the Commission's White Paper, political authorities at both the EU and national levels undertook the role of an official initiator with the prevailing role of the Commission in the EU and the Directorate of Sport within the Ministry of Education and Sport at the national level. The sub-national level in Slovenia was excluded from these processes mainly because the normative legislative basis of this type of political level in Slovenia still does not exist. Despite this, it is worth mentioning that for the consultations relating to amendments to the Slovenian Sports Act that were going on at almost the same time as the White Paper discussions, regional meetings were organised by the government to collect regional comments on the contents. In some sense, this may indicate some sort of inequality in the importance of both acts but, as was pointed out by representatives at the ministry, the national legislation was simply assigned more importance than the Commission's draft White Paper, whose contents was not even known to them at the time the consultations were organised.

The consultation and preparation for the White Paper extended from late 2005 to the adoption of the Document in July 2007. It is possible to classify the preparations for the White Paper according to the actors involved:

1) EU institutions, relating solely to the work of EU institutions;

2) sports-governing bodies, relating solely to the work of private sports organisations' activities;

3) member states, relating solely to the activities of individual states;

4) EU vs. member states, relating to relations between EU institutions and member states' representatives;

5) EU vs. sports-governing bodies, relating to relations between these two types of policy actors; and

6) member states vs. sport-governing bodies, relating to mutual relations between these two types of policy actors.

The available register of official meetings of state actors (ENGSO 2006) reveals that the number of activities initiated by the Commission was greater than activities undertaken solely by member states and quite equally distributed between the state and sportsgoverning bodies' representatives. Alternatively, the interactions between the sportsgoverning bodies and EU institutions, particularly the Commission and its Sport Unit, were also similar in number to those of the EU member states. It is also typical that as a rule those private sports initiatives acted according to the supranational (European) organisational and functional logic, meaning that each organisation represented its own sporting interest more than general sports ones. Based on the official timeline records (Reuters 2007), the leading role was undertaken by FIFA and the European Olympic Committees (EOC). A clear public statement on the processes and issue of the White Paper was also given by the European non-governmental sports organisation (ENGSO). This organisation stated that the attention paid to sport at the EU level had grown in recent years, leading to the recognition that sport can play an important role in EU policies and programmes (ENGSO 2006). Regarding the role of the EU and the relations with its institutions, it emphasises its understanding of the White 
Paper on Sport as 'an important step towards defining the role of the EU in relation to sport and sporting organisations', where the 'ENGSO has a strong desire to work positively with the EC [European Commission] and will respond in detail to the consultation on the White Paper' (Reuters 2007).

However, in a way this recognition indicates that the general logic of the governance approach in the process at the EU level has been considered, at least in a quantitative manner. This focuses above all on an EU-organised type of sports-governing body and member states although it still does not tell us anything about the qualitative aspects, such as those dealing with the nature of the actual relations and (sub-)national responses. This is considered below.

With regard to Slovenia, the intensity of specific activities was very poor. Constant contact in the period of preparing the White Paper was only established with the Sports Unit of the Commission's DG Education and Culture (which is responsible for providing regular information about the progress of member states at meetings with the directors and ministers responsible for sport on one side and other Commission DGs on the other). ${ }^{19}$ As a consequence of this official response to meetings at the EU level, no special meetings were called for policy actors involved and interested at the national level with regard to the White Paper. Thus, only official written or oral notifications about current progress were given to other national actors, namely only to the Expert Council of Sport whose last meeting was held on 20 December 2006 (Expert Council of Sport 2007), which dates to the period before the final consultative activities at the Commission were implemented. From the governmental perspective, the whole process was negatively assessed, claiming that their inactivity could be excused by the independent work of the Commission, seen not only in relation to the nation-state representatives but also private sports-interested publics.

Likewise, as in the case of nation-state actors, an obvious absence of activities in preparation of the White Paper was also seen with regard to national civil sports organisation representatives. As already emphasised, the Commission's Sports Unit held regular consultative meetings with civil sports movements in the EU, but not with the national ones which was, according to the national perspective, another reason for their limited involvement. According to the OCS-ASF's views, they also claimed they had only received very moderate starting points about the White Paper's contents and some kind of recommendations from the European Olympic Committees, which they all discussed and supported, but no other invitation and proposals were sent to them and, therefore, no follow-up consultations were conducted. In fact, a study of the OCS-ASF minutes of their meeting in May 2007 notes that the processes of preparing the White Paper was put on the agenda only for the first time at the session of 17 May 2007, when the deadline for consultations at the EC had already closed (3 April 2007) (OCS-ASF 2007). ${ }^{20}$ Similarly, no international connections between the national sports federations' and the supranational level can be detected or publicly recognised. As stressed by the sports organisations' representatives, no individual or collective initiatives were sent from Slovenia in regard to the White Paper and none of the organisations undertook any role within the already stressed EU-organised sports organisation activities.

\section{National Assessments of the Multi-level Governance Experience}

According to Slovenian experiences, quite negative assessments of the EU processes were made by nation-state and civil society actors. The state representatives particularly perceived the role of the EC in the processes of preparing the White Paper as being too centralistic,

\footnotetext{
${ }^{19}$ Especially those referring to the internal market, health, culture, education, youth, and the legal security of EU citizens were exposed by representatives at the ministry.

${ }^{20}$ Despite this late reaction to the White Paper processes, the OCS - ASF invited the representative of the European Commission in Slovenia to inform them about the ongoing processes in the field of sport in the EU. At their meeting on 21 June 2007 the legal and institutional frameworks as well as the history of sport in the EU were presented to them.
} 
despite considering its formal competencies and procedures in the process of preparing the document. Representatives of the Ministry of Education and Sport also stated there were no demands by the Commission to nominate an official representative for Slovenia. Similarly the processes were also assessed by the OCS-ASF as being very badly communicated since they officially received very few materials for discussion and consideration. Both types of national policy actors also emphasised that they perceived the strength of well-organised European sports interest organisations in the process, although none of the interviewees were aware that any Slovenian sports federation or organisation had participated in these EU sports lobbying activities.

At first sight, it might appear that the decision to analyse the Slovenian perspective in the White Paper's preparation processes was not overly beneficial since there are almost no indications of any kind of national activities connected with the process. It would not be an exaggeration to conclude that no connections between sports representatives at the national level existed as a result of the ongoing White Paper processes, while linkages with state representatives on the topic also reflected their formal obligations as predicted by the national legislation. It is difficult to detect many examples of harmonisation or co-operation between both types of actors at the national and supranational levels. But what is obvious here is a 'dual-track' truth - an important signal not only for the (sub-)national but also supranational level. The absence of the will to search for other ways of addressing the Commission on the national actor's side is undisputed. No type of lobbying can be detected, although at the same time a question of the appropriateness of this approach arose, especially in the case of the state representatives. ${ }^{21}$ These conclusions importantly support the already existing ones regarding the paths Slovenia took in the former 'Europeanisation' processes where, according to Fink Hafner and Lajh (2003: 168-169), the predominant adaptation of Slovenian institutions has so far run in the direction of so-called 'policy-taking', which mainly internalised the common EU legal order and policies, reflecting patterns of gradual, pragmatic and flexible adaptations to the challenges of EU integration. Similar conclusions have also been confirmed in the case of a multi-level analysis of policy processes in the case of cohesion policy in Slovenia (Lajh 2006).

It is also possible to identify the gap between the formal and actual or everyday approaches in the policy-making process in the EU. According to the detected characteristics of multilevel practices in sports governance in the analysed case, we can see that in some sense the type of semi-plural relations between the actors involved at different political levels are only confirmed in the initial phases of searching for policy alternatives (see Greenwood 2007; Schmidt 2006). On the contrary, in the phase of selecting policy alternatives (preparing the final version of the White Paper) the pluralist approach was replaced by a centralist role of the Commission that, according to information independently collected, prepared the final version of the document. Speaking about the nature of jurisdictions, as one of the crucial elements of the governance concept, it is thus possible to perceive some sort of limited jurisdictions, particularly at the national level and in the stage of preparing the final version of the document.

\section{Concluding Remarks: Multi-level Governance or a Form of Supra-national Statism?}

In responding to the main heading regarding how Slovenia comprehends the multi-level processes in shaping sports policy at the EU level, some more or less obvious conclusions can be set out. This shows the fragmentation of multi-level policy-making in a concrete analysed case. Confirming the theoretical conclusions on multi-level governance; the case of the White Paper processes shows that, it is almost impossible to clearly differentiate between different aspects of governance since they are so intertwined. Regarding sports governance; it is possible to detect many political aspects, like the EU constitutional processes and the absence of the sub-national level of consultation in Slovenia, along with the distinctive

\footnotetext{
${ }^{21}$ But according to much research data on lobbying this would of course not be understood as a problem but more as an opportunity (see Greenwood 2007).
} 
inactivity of a whole set of actors at the national level. Policy-making practices and the roles of the policy actors involved at both national and supra-national levels also reveal a perceivable change and specifics in the policy-making style at each level in the field of sport. Followed by the emphasised theoretical elements of governance it is concluded that the ongoing EU and national processes in the field clearly include, as well as respond to the idea of governance, but only when analysed individually. The institutions responsible for sports issues are established and their jurisdictions, activities and outcomes are also expressed in various legal documents. But, despite this, it seems that, particularly in the case of the EU, the youthfulness of sports-related policies can be seen by the fact that the value of sport and institutional identity are still being shaped and in the prevailing manner of the co-ordination activities with other actors; just like the modes and mechanisms for adjusting the conflicting interests of those actors that have the potential and reason to express them. When speaking about the EU relationship to the national perspective, it can be concluded that EU policymaking was not so close to the governance idea, and that the EU actors' positions were too centralistic and, at the beginning of the process, also too semi-pluralist. Following this conclusion, the question of the suitability of the current processes of introducing policy initiatives and, along with them, new policies, launched at the EU level are mainly problematic in the case of actors at the national level. This leads to the topical dilemma of the limits of EU jurisdictions (Hix 1999; Hooghe and Marks 2001; Grant 2003). The question therefore remains whether the member states should have a voice in ongoing processes at the EU level or whether it is enough to treat them as one of many other types of interest that compete to be heard, or if it is their own fault for being inactive or only reactive to the EU processes.

What should also be discussed in connection with the former conclusion, but which has not been addressed more precisely in this contribution, is the issue of political management concerning the role of political and organisational changes that can happen and possibly influence the future of policy-making processes at the level of individual territories. In these terms, the role of the central institution at each level has been emphasised by the fact that for the same processes the actors' jurisdictions on one level are far more decisive than on the other. Therefore, the gap between legally defined and actual everyday processes and procedures of the actors can also be seen, with the Commission at the EU level taking a very pluralist approach to the processes at the beginning and an exclusive one at the end. Such a gap can also be observed in the national level that only formally reacted to the Commission's work, even though the national governance elements seemed to be present and exercised at the national level. Speaking about the policy actors involved, an interesting difference can also be seen between them at both levels. At the EU level, the Commission as the representative of the state-like authority, collaborates more closely with powerful Europeanbased, private, sports-governing interests, such as organised sporting bodies like those of UEFA, FIBA Europe, EHF, EOC or ENGSO 22 , while the co-operation and co-ordination with the national level is looser, if not only implemented because of the legally-based provisions with the role of state representatives still being more exposed than those of the national sports organisations.

Given these conclusions the central dilemma that remains unresolved is to connect the questions of the broad legitimacy and effectiveness of these processes and the jurisdictions of various types and levels of the actors involved to be able to create a broad consensus on the best possible policy alternatives. Although the multi-level governance idea in the case of EU sports policy is in its early infant stage, it is at the same time also very deliberative since

\footnotetext{
${ }^{22}$ A few days after the final version of the White Paper on Sport was publicly submitted, the response of the joint EU private sports interests indicated that their interests and positions were not considered enough (Statement of European team sport 2007).
} 
the contents of the White Paper respond to many of the 'classical' elements of the governance 'ideology'.

\section{References}

Aguilera, V. Ruth, in Cuervo-Cazurra, Alvaro (2004). 'Codes of Good Governance Worldwide: What is the Trigger?', Organization Studies, 25(3), pp. 415-443.

Allison, Lincoln (2006). The Global Politics of Sport (Sport in the Global Society), London: Routledge.

Andersen, Svein and Eliassen, A. Kjell (eds) (2001). Making Policy in Europe, 2nd edition, London: Sage.

Arnaut, José Luis (2006). Independent European Sport Review, available at: <http://www.independentfootballreview.com/doc/A3619.pdf>

Banchoff, Thomas and Smith, Mitchell P. (eds) (1999). Legitimacy and the European Union: The Contested Polity, London: Routledge.

Börzel, Tanja (1997). 'What's So Special About Policy Networks? An Exploration of the Concept and Its Usefulness in Studying European Governance', European Integration online Papers (EloP), 1(16), available at: <http://eiop.or.at/eiop/texte/1997-016a.htm>.

Chaker, André-Noël (2004). Good Governance in Sport. A European Survey, Strasbourg: Council of Europe Publishing.

Council of Europe (2005). Recommendation Rec(2005)8 of the Committee of Ministers to member states on the principles of good governance in sport, available at: <http://www.coe.int/t/dg4/sport/Resources/texts/sprec05.8_en.asp>.

The Council of the European Union (2007). Draft Reform Treaty, available at: $<$ http://www.consilium.europa.eu/cms3_fo/showPage.asp?id=1317\&lang=en\&mode $=\mathrm{g}>$.

Cram, Laura (2001). 'Integration and Policy Processes in the European Union', in Bromley, Simon (eds), Governing the European Union, London: Sage Publications, pp. 143-165.

Crombez, Christophe (2003). 'The Democratic Deficit in the European Union: Much Ado about Nothing?', European Union Politics, 3 (4), pp. 101 - 120.

ENGSO [European Non-governmental Sports Organization] (2006). ENGSO Position Statement on the EC White Paper on Sport, available at:

$<$ http://www.engso.eu/Downloads/ENGSO_Position_Statement_on_the_EC_White_Paper_o n_Sport.pdf $>$.

Expert Council of Sport (2007). Zapisniki in sklepi (Minutes and decrees of the Sessions), available at: <http://www.mss.gov.si/index.php?id=483\%29>.

EurActive (2007). EU opens up Treaty revision with launch of IGC, available at: $<$ http://www.euractiv.com/en/future-eu/eu-opens-treaty-revision-launch-igc/article$165763>$.

European Commission (1998). The European Model of Sport, Consultation Document of DG X.

European Commission (1999) The Helsinki Report on Sport, Report from the European Commission to the European Council with a view to safeguarding current sports structures and maintaining the social function of sport within the Community framework. COM (1999) 644 final, 10 December 1999

European Commission (2001). The White Paper on European governance, COM, 2001/428.

European Commission (2007). The White Paper on Sport, COM, 2007/0391.

European Commission (2007). The EC launches a public consultation on the EU \& Sport, available at:

$<$ http://ec.europa.eu/yourvoice/ipm/forms/dispatch?form=OnlineConsult2007\&lang $=e n>$.

European Council (2000). Declaration on the Specific Characteristics of Sport and Its Social Function in Europe, of Which Account Should Be Taken in Implementing Common Policies, Presidency Conclusions. Nice European Council, 7-9 December 2000, available at: 
<http://www.consilium.europa.eu/ueDocs/cms_Data/docs/pressData/en/ec/00400r1.\%20ann.en0.htm>.

European Parliament (1994). The European Community and Sport. Committee on Culture, Youth and the Media. Raporteur: J. Larive, A3-0326/94, 27 April.

European Parliament (1997). Resolution on the role of the European Union in the field of sports, OJ C 200, 30 June 1997, p. 252.

European Parliament (1997a). The Role of the European Union and Sport. Committee on Culture, Youth, Education and the Media. Raporteur: D. Pack, A4-197/97, 28 May.

Fink Hafner, Danica and Lajh, Damjan (2003). Mapping Europe from Home: The Europeanisation of the Slovenian Core Executive. Ljubljana: Fakulteta za družbene vede.

García, Borja (2007). 'From regulation to governance and representation: agenda-setting and the EU's involvement in sport', Entertainment and Sports Law Journal, 5(1), available at: <http://go.warwick.ac.uk/eslj/issues/volume5/number1/garcia/>.

George, Stephen and Bache, Ian (2000). Politics in the European Union, Oxford: Oxford University Press.

Golub, Jonathan (2007). Survival Analysis and European Union Decision-making, European Union Politics, 6 (8), pp. 155 - 179.

Grabbe, Heather (2001). 'How does Europeanization affect CEE Governance? Conditionality, Diffusion and Diversity', Journal of European Public Policy, ((6), pp. 1013-1031.

Grant, Wyn (2003). 'Multi-level governance', in McLean Ian and McMillan, Alistair (eds) The Concise Oxford Dictionary of Politics, Oxford: Oxford University Press, Oxford Reference Online, available at:

<http://www.oxfordreference.com/views/ENTRY.html?subview=Main\&entry=t86.e85 $5>$.

Green, Mick and Houlihan, Barrie. (2006). Governmentality, Modernisation and the 'Disciplining' of National Sporting Organizations: An Analysis of Athletics in Australia and the United Kingdom, paper presented at the ECPR Joint Sessions of Workshops, Nicosia, Cyprus, 25-30 April.

Greenwood, Justin (2007). Interest Representation in the European Union. Second Edition, Palgrave.

Governance Hub (2007), available at: <http://www.governancehub.org.uk/>.

Henry, P. Ian (2004). The Politics of Leisure Policy, Houndmills: Macmillan.

Héritier, Adrienne (2002). 'New Modes of Governance in Europe: Policy-Making Without Legislation?', in Héritier, Adrienne (eds), Common Goods: Reinventing European and International Governance, Lanham: Rowman and Littlefield.

Hix, Simon (1999). The Political System of the European Union, Macmillan Press.

Hooghe, Liesbet and Marks, Garry (2001). 'Types of Multi-Level Governance', European Integration online Papers (ElOP), Vol. 5 (11), available at: <http://eiop.or.at/eiop/texte/2001-011a.htm>.

Houlihan, Barrie (2002). 'Politics and Sport', in Coakley, J. and Dunning, E. (eds), Handbook of Sports Studies, London: Sage Publications, pp. 213-227.

Houlihan, Barrie and White, Anita (2002). The Politics of Sports Development. Development of Sport or Development Through Sport?, London: Routledge.

Houlihan, Barrie (2003). 'Sport and Globalisation', in Houlihan, Barrie (eds), Sport \& Society. A Student Introduction, London: Sage, pp. 345-364.

Ibsen, Bjørne (2006). Sport and Welfare Policy in Denmark, paper presented at the ECPR Joint Sessions of Workshops, Nicosia, Cyprus, 25-30 April.

Independent European Sports Review (2006). UK Presidency Initiative on European Football Context and Terms of Reference, available at: <http://www.independentfootballreview.com/terms.html>

Kohler - Koch, Beate (2005). 'European Governance and System Integration', European Governance Papers, C-05-01.

Kustec - Lipicer, Simona (2007). 'Sports Policy in Slovenia: the forms of state intervention over time', Transitions, 47 (1), pp. 73-93.

Lajh, Damjan (2007). Evropeizacija in regionalizacija: spremembe na (sub)nacionalni ravni in implementacija kohezijske politike v EU v Sloveniji (Europeanisation and Regionalisation: Changes on (Sub)National Level and Implementation of Cohesion Policy in the EU in Slovenia), Ljubljana: Fakulteta za družbene vede. 
Marks, Garry (1993). 'Structural Policy and Multi-level Governance in the EC', in Cafruny, A. and Rosenthal, G. (eds), The State of the European Community, vol. ii: the Maastricht Debates and Beyond, Boulder: Lynne Rienner, pp. 391-410.

Mayntz, Renate (2004). 'Governance Theory als fortentwickelte Steureungstheorie?', Working Paper 04/1. Köln: Max-Planck-Institut.

National Programme of Sport in Republic of Slovenia (2000). The Official Gazette of RS, 24/2000.

Olympic Committee of Slovenia - The Association of Sport Federations (2007). Zapisnik 4. seje IO OKS (Minutes of the $4^{\text {th }}$ Session of the Executive Board), available at: <http://www.olympic.si/uploads/media/ZAPISNIK_4._SEJA_IO_OKS.doc>.

Parrish, Richard (2003). Sports Law and Policy in the European Union, Manchester: Manchester University Press.

Pierre, Jon, and Peters, Guy (2005). Governing Complex Societies. Trajectories and Scenarios, Palgrave.

Reuters (2007). Factbox - Timeline of EU white paper on sport, available at: $<$ http://uk.reuters.com/article/footballNews/idUKL1171670520070711>.

Rhodes, Rhode (1996). 'The new governance: governing without government', Political Studies, Vol. 44, pp. 652-667.

Richardson, Jeremy (eds) (1996). European Union: Power and Policy- Making. London: Routledge.

Robinson, Mark (2004). 'Governance', in Kuper, V. A. and J. (eds), The Social Science Encyclopedia. Third edition, Routledge: Routledge Reference Resources online, Taylor \& Francis Publishing Group, available at: <http://www.reference.routledge.com/subscriber/entry?entry=w104_w104b197>.

Sam, Michael P. and Jackson, Steven J. (2004). 'Sport Policy Development in New Zealand: Paradoxes of an Integrative Paradigm', International Review for the Sociology of Sport, 6 (39), pp. 205-222.

Schmidt, A. Vivien (2006). 'Procedural democracy in the EU: the Europeanization of. national and sectoral policy-making processes', Journal of European Public Policy, 13(5), pp. 670-691.

Schneider, Volker (2004). 'State Theory, Governance and the Logic of Regulation and Administration Control' in Warntjen A. and Wonka A. (eds), Governance in Europe. The Role of Interest Groups, Baden-Baden: Nomos, pp. 24-41.

Statement of the European team sports (2007). EU White Paper on sport: much work remains to be done, available at: <http://www.uefa.com/newsfiles/560350.pdf $>$.

Sports Act (1998). Official Gazette of RS, 22/1998, 27/2002, Decree of the Constitutional Court: U-I-210/98-32, 110/2002, 15/2003.

Treaty establishing a Constitution for Europe, OJ C 2004/310: 127.

Treib, Oliver, Bähr, Holger, and Falkner, Gerda (2007). 'Modes of Governance: A Note Towards Conceptual Clarification', Journal of European Public Policy, 14/1, pp. 1-20.

United Nations (2007). What is good governance, available at:

$<$ http://www.unescap.org/pdd/prs/ProjectActivities/Ongoing/gg/governance.asp>.

Verovnik, Zoran (eds) (1999). International Acts in the Field of Sport. International Conventions and Charters on Sport, Ljubljana: Ministry of Education and Sport.

Wälti, Sonja, Kübler, Daniel, and Papadopoulos, Yannis (2004). 'How Democratic is Governance? Lessons from Swiss Drug Policy', Governance, 17(1), pp. 83-113.

World Bank (2007). What is our approach to governance?, available at:

<http://web.worldbank.org/WBSITE/EXTERNAL/WBI/EXTWBIGOVANTCOR/0,,contentMDK:206 78937 pagePK:64168445 piPK:64168309 theSitePK:1740530,00.html>.

Wright, Vincent (1996). 'The National Co-odrination of European Policy-Making: Negotiating the Quagmire', in Richardson, J. Jeremy (eds), European Union: Power and PolicyMaking, London: Routledge, pp: 148-170. 